DOI: 10.19195/0137-1150.168.26

Data przesłania artykułu: 23.05.2017

Data akceptacji artykułu: 16.01 .2018

\title{
JÁN GALLIK
}

Univerzita Konštantína Filozofa v Nitre, Słowacja

\section{Motív smrti v tvorbe autorov slovenskej, českej a mad’arskej katolíckej literatúry}

\author{
Smrt' je nedefinovatel'ný faktor. \\ Ale ňou začína múdrost' sveta i poézie ${ }^{1}$.
}

Zložité spoločensko-politické a hospodárske podmienky 30. rokov 20. storočia (nielen) v Európe ${ }^{2}$ sa začali postupne čoraz výraznejšie odzrkadl'ovat' i v literárnom živote stredoeurópskych národov. V kontexte príspevku máme na mysli najmä česko-slovenský i mad’arský literárny život. Jaroslav Med v publikácii Literární život ve stínu Mnichova (2010) poukázal na fakt, že kým v 20. rokoch 20. storočia prevažovala optimistická snaha o identifikáciu s novým štátom (ČSR), pričom spisovatelia sa prevažne prezentovali programovo zomknutými skupinami (proletárska literatúra, poetizmus), tak už na začiatku 30. rokov 20. storočia začína prevažovat' značná individualizácia tvorivých a ideových postupov. Akoby sa

vytrácel vývojový optimizmus poválečných let a místo něho nastupovalo existenciální tázání po smyslu života a smrti — není jistě náhodné, že právě v roce 1930 vychází trojice básnických knih (V. Holana Triumf smrti, F. Halase Kohout plaši smrt a J. Zahradníčka Pokušení smrti), zřetelně manifestující tento existenciální rozměr ${ }^{3}$.

* Štúdia vznikla na základe riešenia projektu VEGA 1/0060/15 s názvom Katolícka literatúra $v$ stredoeurópskom priestore.

${ }^{1}$ P. Strauss, Kolíska dôvery, Trnava 1994, s. 91.

${ }^{2}$ Napr. najväčšia svetová hospodárska kríza v moderných dejinách, vznik fašizmu v Taliansku, nástup Adolfa Hitlera k moci v Nemecku, občianska vojna v Španielsku.

3 J. Med, Literární život ve stínu Mnichova (1938-1939), Praha 2010, s. 29. 
V tomto kontexte je zaujímavou osobnost’ou český krest’anský básnik Bohuslav Reynek, ktorý povojnové avantgardné predstavy človeka, to jest príval vitalizmu, materializmu, kolektivizmu a podobne, vnímal ako chaos a ničotu. V jeho ranej tvorbe prevláda absolútna viera $\mathrm{v}$ Boha, ktorá dáva vykupitel’ský zmysel všetkému. Kým utopizmus

avantgardy snil o bezbřehé budoucnosti, Reynkův tragismus vnímal konečnost jako jediný předpoklad pro smysluplné naplnění budoucnosti. „Krásné a spravedlivé jest umírání“ smrt je „naší sestrou“, smrt je „horou slastí“ a smrt také ruší jakékoli svobody soudobého kolektivismu“.

Treba však uznat', že v celkovom kontexte vývoja náboženskej tvorby, a teda aj poetiky slovenskej, českej či mad’arskej katolíckej literatúry, nie je motív smrti niečím neobvyklým. Tento fakt je zjavne viditel'ný aj v dielach autorov z prelomu 19. a 20. storočia a tiahne sa takmer celým 20 . storočím s presahom do tretieho tisícročia. Napríklad v prvej fáze tvorivého obdobia Jakuba Demla, považovaného za jedného z najvýznamnejších predstavitel’ov českej katolíckej literatúry prvej polovice 20. storočia, zrkadliacej sa v tzv. apokalyptickom realizme, evidujeme výraznú tematizáciu samoty, smrti, zániku a ničoty. Smrt' je v Demlovom diele 5 predstavená aj ako entita, ktorú človek hladá s istou vyzývavost’ou a túžbou, pričom „ustavičně potkává Život. Ale jakmile se rozhorlí a hledá Života, ustavičně potkává Smrt; i ten kdo ho nehledá sobě“ ${ }^{\text {‘6 }}$ U vyššie spomenutého Jana Zahradníčka, kto-

${ }^{4}$ J. Med, Spisovatelé ve stínu, Praha 2004, s. 95.

5 Jaroslav Med vníma smrt' v dielach Jakuba Demla Hrad smrti (1912) a Tanec smrti (1914) najmä ako ničitel'ku všetkého, pochovávajúcu každý prítomný okamih budúcim okamihom, aby človeka mučila plynutím času. Jediným útočiskom je žit' smrt' ako danost', zjednotit' v jej priesečníku čas $\mathrm{s}$ večnostou a dat' životu tvorivý rozmer bud' slovom alebo láskou k inej bytosti. Týmto spôsobom si vysvetl'uje i simultánny vznik Demlových diel plných vrúcneho citu, akými sú Moji prátelé (1913) a Miriam (1916), popri vyššie zmieneným. Práve Demlova najvydávanejšia a čitatel'sky najpopulárnejšia kniha Moji prátelé predstavuje jeden z vrcholov jeho tvorby. „Tyto proslulé apostrofy květin nejsou františkánsky prostou oslavou přírody, jak bývají často interpretovány, protože vše tu probíhá na temném pozadí básníkova prožitku ohroženosti lidské existence smrtí. Květiny, zástupní symbol veškeré krásy a něhy, stojí v př́íkrém protikladu $\mathrm{k}$ temnému světu utrpení a smrti. Jediná moc, která může tuto protikladnost zrušit, je láska“ (J. Med, Spisovatelé ve stínu..., s. 60). Tento názor J. Meda dokazuje aj nasledovný Demlov text: „VLČÍ MÁKU, vidím město orientální, je obklíčeno vysokou zdí. / Slunce v plném květu na nebi i na zemi. / Podél městských hradeb — vid', kosti vybělené sluncem svaté jsou? - jde dívka, ruce napřažené, obličej / obrácený k nebi. / Kam jdeš? / Do Města. / Ale tudy se nejde do Města. / Pane, já nevidím. / Bolí tě, že nevidíš? / Pane, já nevím. / Tedy jsi dosud nemilovala? / Očima ne, pane. / A jak se ti to stalo? / Když jsem byla maličká, zírala jsem do ohně. / A pamatuješ, jaké je nebe a jaká je země za krásného dne, anebo za jasné, čisté noci? / Pane, já jsem byla maličká. Vidělas Smrt? / Jen jsem ji slyšela. / A nebojíš se jí? / Neumru, když mě viděly Jeho oči. / Čí oči? / Třeba vaše, pane; já nevím, nevidím. / V tom jsme si podobni. / Tak? I vy, pane? / Baže, dcero; vidím sice lilie polní, něhu dalekých obzorů, bílá města, širý úsměv moře, radostné strnutí / palem, let orlů na horách, hluboký pohled blankytu, ale to vše, to vše se velmi podobá vidění tvému, a ve / spaní jsme si zcela podobni... / Nu, a jaký by tedy byl rozdíl podstatný? / Já, doufám, věřím. / Abyste více viděl? / Abych mohl více milovati“. (J. Deml, Moji přátelé, http:// www.deml.cz/moji-pratele [prístup: 10.03.2017]).

${ }^{6}$ J. Deml, Sen jeden sviti, Praha 1991, s. 53. 
rý patril k mladšej generácii, nadväzujúcej z hladiska spirituálne orientovanej tvorby na silnú generáciu českých katolíckych autorov, akými boli Josef Florian, Jakub Deml či Jaroslav Durych, je celá debutová zbierka Pokušení smrti (1930) doslova presýtená motívom smrti. Deklaruje to nielen skutočnost', že smrt' je nosnou súčast’ou samotného názvu básnickej zbierky, ale aj gradácia tohto motívu hned' v úvodných básňach Pokušení smrti a Poetika. A práve úvodné dvojveršie prvej menovanej básne, otvárajúce bránu do Zahradníčkovho debutu, zaznieva nasledovným spôsobom: „Obklopen zástupy svých žalujících stínů / nedovedu již odolávat sladkým pokušením smrti“" , pričom básnik v d’alších veršoch predstavuje lyrický subjekt v područí utajovaného, priam silou vôle zadržiavaného, kŕčovitého žial'u, ktorý pramení v osobnom utrpení:

S uzarděním jsem polykal svůj žal / Tísnivé události vstupovaly do mého těla / osvětleného zevnitř vzníceným keřem nervů / nalomeného větrem bolesti // Proč dále tímto podnebím přikrývat bědnou nahotu? / Úpět pod sžírajícím pláštěm ovzduší / věčně se z něho převlékat / a nevědět že je to smrt // Dychtit po nehmatatelném šatě ohně mučedníků / zahodit drtivou př́itěž starých nadějí a zvyků / Odložit své obnošené tváře jež byly jen vnější / jak tato země odkládá roční počasí jsouc stále posupnější / Vyklouznout $\mathrm{z}$ růžemi ran potřísněné košile své kůže / Na zdrcující něhu zemřelých ponenáhlu si zvykám / Sesouvám se pod jejich tíživými doteky / a nenaříkám nenaříkám / vzývaje sladká pokušení smrti v této nehostinné zemi / Stín z kř́ídel stěhovavých ptáků padá na květy / a na řídnoucí obyvatele padá za noci strach / když stíny pohozených dětí míhají se v sasankách ${ }^{8}$.

V analogickom tematicko-motivickom ladení pokračuje i v druhej menovanej básni, pričom „,podobu smrti“ predstavuje akoby l'útost' lyrického subjektu nad spáchanými hriechmi, v zmysle previnenia sa proti čistote, cudnosti, priam posvätnosti tela. Editori, a zároveň autori komentárov, publikácie Jan Zahradníček: Knihy básni (2001) Jitka Bednářová a Mojmír Trávníček, poukazujú na fakt, že debutová zbierka bola napísaná $\mathrm{v}$ dobe Zahradničkových vysokoškolských štúdií v Prahe v rokoch 1928-1930. Možno z nej vybadat' vplyv expresionistu Georga Trakla, pričom kritici v nej rozpoznávajú i vplyv francúzskeho symbolizmu, asi najviac cez prizmu tvorby Charlesa Baudelaira, ktorého Zahradníček v čase svojich univerzitných štúdí zanietene čítal v origináli. „Vypovídá subjekt, který sebe reflektuje, v sobě se zhlíží, je zaměřen na pochody vlastního těla, výpověd' z něho vychází a k němu se navrací. Základní ladění sbírky spatřují kritikové v pocitu životní marnosti a kusosti, v utrpení a bolesti“‘9. Autori publikácie Přehledné dějiny literatury II (1994) zas chápu motív smrti v Zahradníčkovej debutovej zbierke ako ten, ktorý „se mu stává klíčem k pochopení života i jeho přechodných radostí‘ ${ }^{\prime 10}$.

V kontexte tematiky smrti sú teda zaujímavé i dôvody, ktoré často výrazne ovplyvňovali autorov pri výbere takto profilovanej témy a jej leitmotívu. Rovnako, ako v istom období svojej tvorby vnímal Jakub Deml výraznú spätost' medzi

\footnotetext{
7 J. Zahradníček, Knihy básní, Praha 2001.

8 Ibidem.

9 Ibidem.

${ }^{10}$ B. Balajka, Z. Blajer, E. Charous, Přehledné dějiny literatury II, Praha 1994, s. 70.
} 
samotou a smrtou, tak i dvanástročný židovský chlapec Pavol Strauss, ktorý sa ovel'a neskôr stáva jednou z najvýraznejších osobností slovenskej spirituálnej (kristocentrickej) literatúry, známa pod pojmom slovenská katolícka moderna, a ktorý vo svojich 30 rokoch (to jest v roku 1942) konvertoval zo židovstva na katolicizmus, si prvý raz uvedomil a pocítil desivú samotu okolo seba, ako predzvest' smrti a začal si písat' denník, aby sa nestratil do úplnej opustenosti, ale aby zanechal za sebou stopu, s ktorou a v ktorej by pretrvával: „Ó, to št’astie a istota, že vždy budem, ak ostane niečo na papieri!“"11. V jeho esejistickej tvorbe je práve motív smrti jedným z nosných pilierov, a to z toho dôvodu, vol’ne parafrázujúc Straussov názor, že človek začína byt' človekom, ked' ráta so smrtou a záujmom o smrt' sa vôbec nekončí záujem o život, skôr sa tým umocní, pretože nič nie je definitívne, ani človek. Rozhodujúcim faktorom v Straussovom ponímaní je príprava na smrt', ktorú chápe ako „usmernenie na Krista vo všetkom a všetkým“"12. I Martin Koleják, autor monografie Pavol Strauss, hladač pravdy (2013), venoval práve poslednú kapitolu svojej publikácie s názvom Smrt' a pravda nesmierne významnej entite smrti, ktorá preniká celým Straussovým dielom. Zvýrazňuje najmä Straussovo ponímanie smrti v súvislosti s l’udským egoizmom a materialistickým hedonizmom. Nútili ho k tomu najmä tragické vojnové udalosti, ktoré sa v 20. storočí odohrávali vo svetových i lokálnych rozmeroch, pretože človek akoby prestal rátat' so zánikom života:

Len ho chlípe vel'kou lyžicou, až do opojného šera nastávajúceho večera. A tak chodíme vedla seba ako bezcitné tône dobre oblečených a najedených bábok, bez večnostného zakotvenia, zbytočne narážajúc do seba, ako neuvedomení kandidáti skutočného alebo atómového krematória. A láska je neláska, vzt’ahy sú na zhrdzavených vzpruhách banality, prilepení sme na klzkej podložke odrazového mostíka pred absolútnom, nediferencovatel'né objekty budúceho sna inferna ${ }^{13}$.

V podobnom duchu písal o smrti na samom začiatku nášho letopočtu a v čase vel'kého vojenského, politického a hospodárskeho rozmachu rímskeho štátu už stoický filozof, štátnik a spisovatel' Lucius Annaeus Seneca. Práve v súvislosti s hedonizmom, morálnym úpadkom a despotizmom vládcov poukazoval na dehumanizáciu rímskej spoločnosti, vyvolávajúcu bezprostrednú reakciu v podobe filozofickej a etickej reflexie. Otázka znie, čo pripomínajú Senecove slová súčasníkovi?

Pri všetko sa hl'adá rozkoš. Nijaká chyba nezostáva len vnútri seba. Hýrivost' sa rúti opreteky do lakomstva a človek celkom zabudol na počestnost'. Nič nie je hanebné, ak sa nám páči jeho cena. Pre zábavu zabíja sa človek, ktorý by mal byt' posvätnou vecou druhému človeku, a toho, komu kedysi $\mathrm{k}$ hanebnosti pričítali, ak sa vycvičil na dávanie a prijímanie úderov, toho teraz nahého a bezbranného verejne predvádzajú a divadlo neuspokojuje dostatočne, kým sa nedosiahne jeho smrt'. Preto pri tejto zvrátenosti mravov obyčajne sa intenzívne túži po niečom, čo by rozmetalo iné zostarnuté zlá ${ }^{14}$.

11 P. Strauss, Človek pre nikoho, Bratislava 2000, s. 150.

12 J. Rybák, Posledný rok s Pavlom Straussom, Gelnica 2015, s. 20.

13 P. Strauss, Človek..., s. 145-146.

14 D. Hajko, Antické provokácie, Bratislava 2016, s. 66-67. 
Senecov prístup k smrti, ale i mnohých stoikov, bol založený na chápaní života, ktorý je bytím k smrti. Pochopenie svojho vzt’ahu k smrti má človeku pomôct' vyriešit' vlastný postoj $\mathrm{k}$ životu. Na základe toho odporúčali neodd’al'ovat' začiatok mravného života, ale je potrebné „naplnit' prítomný čas bez odkladu mravnými činmi““15. V stoickom chápaní smrti v kontexte umenia „správne žit’ a správne zomriet"“ však absentovala viera v posmrtný život. Pavla Straussa ale smrt' fascinovala i preto, že sa ju snažil pochopit’ jednak v súvislosti s kategóriou Boha, hoci si uvedomoval, že práve tak, ako nemožno l'udským poznaním obsiahnut' jeho transcendentnost', nemožno akoukol'vek dôkladnou analýzou pochopit' podstatu smrti, a jednak z pozície lekára, vedca, ktorý smeruje aspoň za aproximatívnou úplnostou, pretože i čriepky môžu symbolizovat' celok. Jeho úvahy o smrti tak majú i pre dnešok výrazne nadčasovú platnost', pretože i v súčasnosti je smrt' akoby zdegenerovaná na banálnu a bežnú udalost', pričom, ako sa Strauss viackrát vyjadril, je to paradoxne najdôležitejšia chvíl'a života. Človek má totiž nesmrtel'nú dušu a je povolaný k životu vo večnosti.

Len o dva roky mladší od Pavla Straussa bol básnik a kňaz Pavol Ušák Oliva (vlastným menom Pavol Ušák), považovaný za obrovský talent a nádej slovenskej katolíckej moderny, dá sa povedat' jej novej fázy, tzv. štvrtej generácie básnikov, nazývaných aj „piráti krásy“16. Narodil sa roku 1914 v obci Kátlovce pri Trnave a zomrel vel'mi mladý na tuberkulózu v Kvetnici roku 1941. Pirátom krásy venoval aj svoju jedinú básnickú zbierku Oblaky (1939). O štyri roky neskôr, to jest rok po básnikovej smrti, mu z vd’aky jeho verní druhovia — piráti krásy — venovali „knihu spomienok“, obsahujúcu i Olivove básne z rukopisnej pozostalosti, s názvom Tak umieral básnik Palo Oliva (1942). Zostavil ju Janko Silan spoločne s Mikulášom Šprincom. Základným obrazom Olivovej subtílnej lyriky je zväčša nostalgický smútok. Vel’mi výrazným motívov je však v Olivovej básnickej i prozaickej tvorbe svätá Panna, ktorá bola pre mladého klerika najvyšším ideálom. Najvýraznejšie je mariánsky motív zastúpený v poslednej časti Olivovej debutovej zbierky Oblaky, konkrétne $\mathrm{v}$ šest'dielnom cykle s polytematicky nahusteným obsahom, ktorý nazval Madone. Originálnou metaforikou zosobnil nepoškvrnenú Pannu, ktorá po svojom nanebovstúpení tol'ko ráz poctila l'udí svojím zjavením sa (Oliva spomína zjavenie sa sv. Bernadette v Lurdoch či La Salettské zjavenie sa dvom pastierom, Melánii a Maximovi, ktoré má svoje osobitné postavenie v básnickej tvorbe Jana Zahradníčka), aby im dokázala, ako vel'mi jej na nich záleží. Zvlášt' kladie básnik dôraz na význam Máriiných siedmich rán, príznačných pre Sedembolestnú Pannu Máriu, ktorú v roku 1966 vyhlásil pápež Pavol VI. za hlavnú patrónku Slovenska. $\mathrm{K}$ danému šest'dielnemu cyklu treba priradit' i báseň Ružomberskej Madone, ktorú

15 Ibidem, s. 79.

${ }^{16}$ Básnici Pavol Ušák Oliva, Janko Silan a Mikuláš Šprinc (všetci sa narodili v novembri 1914), ktorých literárna kritika zarad’uje do umeleckého zoskupenia s názvom slovenská katolícka moderna, sa v časoch štúdia v spišskokapitulskom seminári nazvali pirátmi krásy, pretože ich ciel'om bolo hl'adat' a objavovat' krásu v slove, prírode a Božom stvorení. Medzi „pirátov“ patril aj augustínovský prekladatel’ Ján Kováč a organizátor edície Slovo — Štefan Schelling. 
Július Pašteka, editor dvojdielneho súboru diela Pavla Ušáka Olivu, vydaného v roku 2004, zaradil do cyklu tzv. predsmrtných básní s názvom Zvädli kvety osudné. V meditatívnom híbaní nad znepokojujúcimi otázkami života a smrti, ked’ si básnik uvedomuje koniec svojej životnej púte, sú tieto mariánske básne modlitbovým prejavom nesmierne zbožnej adorácie, v ktorých však nejde len o citové vzplanutie, ale najmä o intelektuálnu reflexiu nad ,fascinujúcim zjavom a tajomstvom Nepoškvrnenej, ktorú nemožno celkom vystihnút' tradičnými teologickými ani poetickými invokáciami“"17:

Ty, / biela ako kŕdel' lastovičiek v južnom mori, / Královná slabých, ktoré k ránu padnú, / môj breh sa všade do priepasti borí, / nauč ma premôct' túto silu zradnú. // Modlím sa k Tebe, biela Pani v Ružomberku, / modlím sa k Tebe, vel'ká pani z mramora, / k nohám ti skladám svoju biedu vel'kú, / $\mathrm{k}$ nohám Ti skladám slzy raneného javora ${ }^{18}$.

Snaha po reflexii metafyzična privádza napokon Olivu k napísaniu vel'kolepej básne Fragment, ktorú i český literárny vedec Petr Kučera označil vo svojej štúdii s názvom Žánr katolické poezie v postmoderni situaci (2015) za jeden z najpôsobivejších dialogických textov. Básnik si v nej kladie množstvo nezodpovedaných otázok. Je to akoby jeden z posledných rozhovorov autora s nenávratnom:

Povedzte, ktorým smerom idú vlaky, / povedzte, ktoré vlaky idú nad oblaky? // Povedzte, kam odnesie víchor unavených vtákov, / povedzte, kde sa končí odysea vrakov? // Povedzte, kam zapadne hviezda, ked' je všetko biele, / povedzte, ako d’aleko je od nedele do nedele? // Povedzte, prečo v noci smrt' mi siaha na hrdlo, / povedzte, prečo v srdci s krvou niekol'ko slov zatvrdlo? // Povedzte, prečo tento pozdrav nedopíšem, / povedzte, prečo smrt' nám vlieva do sídc farbu višieň? // Povedzte, prečo nikdy nevrátia sa lanské snehy? / Zbohom, môj básnik krutosti a nehy! // Povedzte, prečo v lúčení sa podobáme kvetom, / povedzte, prečo južní vtáci zaplakali pred odletom? // Povedzte, prečo kvety vädnú — aj na oltári Božom? ${ }^{19}$

Jana Juhásová v monografii Od symbolu k latencii $(2016)^{20}$ poukazuje v rámci analýzy eschatologickej obraznosti autorov slovenskej katolíckej moderny (najmä u Rudolfa Dilonga či Janka Silana) — na tvorbu Pavla Ušáka Olivu, ako na isté vychýlenie sa od tradične ustálenej koncepcie, ktoré rezonuje v dielach autorov daného zoskupenia, ktorí vzhl’adom aj na svoj kňazský status vnímali smrt' ako prechod do hierarchizovaného posmrtného bytia ${ }^{21}$. „Raj bol zobrazovaný ako miesto

${ }^{17}$ P. Oliva, Torzo literárneho diela I, Bratislava 2004, s. 35.

18 Ibidem, s. 100.

19 Ibidem, s. 101.

20 Jej základným ciel’om je postupne odhalit' na istej vzorke textov „spirituálnych básnikov“, ktorých inšpiračným zdrojom je najmä krestanská tradícia, podoby súčasnej lyriky so spirituálnym charakterom.

${ }^{21}$ Treba ešte dodat', že v medzivojnovom období zobrazenie motívu smrti, založeného na spirituálnych konotáciách, nebol privilégiom len pre autorov duchovno-krest’anskej tvorby. Ivica Hajdučeková v monografii Duchovnost’v (re)interpretácii diel v slovenskej literatúre (2016) výrazne vníma motív smrti i u autorov prózy naturizmu (najmä u Dobroslava Chrobáka a Františka Švantnera) ako istý transcendentný príznak často predznamenávajúci moment znovuzrodenia, premeny, doslova „nového“ života. 


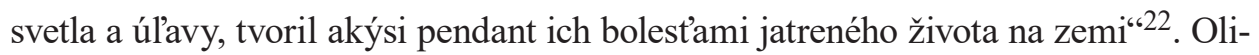
vovo vychýlenie sa od tohto modelu bolo podla nej spôsobené najmä zosilneným strachom pred smrtou. Pavol Ušák Oliva bol teda skutočne básnik presvedčený o večnosti slov, prinášajúcich na tento svet reč královskú, rajskú, ako to o básnikovi napísal v spomienkovom liste d’alší ,pirát krásy“ Števo Schelling ${ }^{23}$. Zostáva preto skutočne vel'kou škodou, že sa tento spirituálny básnik, tvorca imaginatívnej katolíckej poézie, nemohol dožit' dlhšieho veku.

Hoci mad’arskú literatúru nemožno, samozrejme, radit' medzi slovanské literatúry, je však s viacerými v priestore strednej Európy vel'mi úzko spätá, a to z hl’adiska geografického, historického, kultúrneho, spoločensko-politického (v kontexte danej štúdie máme na mysli najmä hrozné skúsenosti s dvoma totalitnými režimami 20. storočia) a tak d’alej. Ako uvádza Martin C. Putna v štúdii s názvom Katolicismus v moderni mad'arské literatuře aneb Nejen dědictvi svatého Štěpána, ktorá tvorí prológ do antológie mad’arskej katolíckej literatúry preloženej do českého jazyka a zostavenej editormi Róbertom Kiss Szemánom a Simonou Kolmanovou pod názvom Němá nauka stromů o spáse (2014), práve Česko a Uhorsko, súčast’ou ktorého bolo do roku 1918 i Slovensko, majú totiž v rámci kultúrnych a duchovných dejín vela spoločného a podobného. O tom svedčí i fenomén formovania málo známych analógií slovenskej, českej a mad’arskej katolíckej literatúry v 20. storočí, ktorý je plný súvislostí, čo je v prvom rade dané už spomínaným zdiel’aním spoločného stredoeurópskeho priestoru.

Jak bylo již mnohokráte napsáno: katolická literatura vzniká v důsledku sekularizace. Je projevem „druhé konfesionalizace“, tedy vytvářením ostře vyhraněných nábožensko-politických názorových táborů uvnitř moderní společnosti. Čím více je tradiční katolická část společnosti zatlačována na okraj moderního vývoje, tím zřetelněji buduje „paralelní polis“, „katolické milieu“, a v jeho rámci jako jeden z prostředků upevňování, uvědomování a vzdělávání komunity i specifickou katolickou literaturu ${ }^{24}$.

V súvislosti s témou príspevku nás bude zaujímat' najmä tvorba Jánosa Pilinszkého, považovaného za jedného z najvýznamnejších mad’arských spisovatel’ov druhej polovice 20. storočia, ako predstavitel'a štvrtej mad'arskej literárnej modernity (generácia zoskupená okolo časopisu „Nyugat"). Patril ku generácii autorov, ktorá sa hlásila o slovo v 40. rokoch 20. storočia (svoje prvé básne publikoval roku 1941 v časopise „Magyar Csillag“), najmä však po skončení druhej svetovej vojny. So svojimi generačnými druhmi sa stal autorom a nejakú dobu i spoluredaktorom časopisu „Újhold“ (1946-1948). Svojou tvorbou nadväzoval na odkaz velikána prvej generácie „Nyugatu“ Mihálya Babitsa, pričom sa hlásil najmä „k jeho syntéze víry a rozumu, estetických nároků na dílo i neokázalé společenské angažovanosti - ve smyslu ochrany humanistických občanských hodnot - touhy po

22 J. Juhásová, Od symbolu k latencii, Ružomberok 2016, s. 60.

23 P. Oliva, Tak umieral a žije Pal’o Oliva 2, Bratislava 2004, s. 43.

24 Němá nauka stromů o spáse. Antologie mad’arské katolické literatury, eds. R. K. Szemán, S. Kolmanová, Praha 2014, s. 8. 
poznání i pevných morálních kvalit“²5. Pokial’ ide o svetovú literatúru, tak hlavne jeho poézia nadväzuje na diela francúzskej katolíckej literatúry (Françoisa Mauriaca), ale aj existencialistu Alberta Camusa, resp. Thomasa Stearnsa Eliota,Gottfrieda Benna i Paula Celana, či na diela Fiodora Dostojevského a Franza Kafku.

V štúdii doteraz analyzovaný motív smrti — a s ním súvisiace motívy v dielach vybraných českých a slovenských katolíckych autorov — nadobúda v niečom analogický, ale v mnohom aj špecifický rozmer v kontexte básnickej i esejistickej tvorby J. Pilinszkého. Autor zobrazuje vo svojich dielach opustenost', osamelost', utrpenie a pominutel'nost' najmä cez optiku osobnej skúsenosti s ,nenapravitel'ným škandálom“, ako nazýva hrôzy druhej svetovej vojny a zvlášt' samotný holokaust. Práve zbierka Harmadnapon (Na tretí deň), ktorá vyšla v roku 1959, pričom v rokoch 1951 až 1956 autor nemohol publikovat', obsahuje viaceré básne, ktoré nesú vo svojom názve konkrétny údaj, to jest miesto a dátum, odrážajúci podstatu zažitej udalosti. Ide o básne ako Harbach 1944, Ravensbrücká pašije či Frankfurt (signovanú posledným veršom Frankfurt 1945), pričom aj v úvodnom obraze nosnej básne celej zbierky, nazvanej v českom preklade Třetího dne, odkazujú „,ravensbrücké stromy“ priamo na lokalitu lágra ${ }^{26}$. V prvej zmienenej básni upriamuje autor pozornost', vychádzajúc zo svojich spomienok (,Mám před očima je zas a zas“27), na zotročené a vyhladované telá l'udí, tlačiace obrovský nehlučný voz, pričom len „stíny těl mrtvých sousedů / vrůstají přitom do jejich / a pomáhají jim klopýtat; / navzájem ve svých šlépějích“ ${ }^{28}$. Smrt' je tu vnímaná ako entita, ktorej blízkost' je neodmyslitel’ná, mnohým pripadá ako jediná možnost' vykúpenia z neznesitel'ných múk a utrpenia, pretože telá už akoby patrili nemote: „Tváře do výšin ubozí / napjatě noří, snad větří tam / dálné nebeské úvozy. // Vždyt', připravena už přijmout vše / jak ohrada, jež

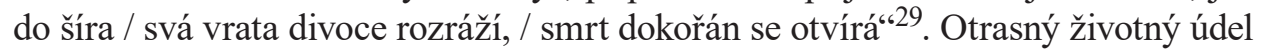
l'udí, z ktorých holokaust spravil „ciel' číslo jeden“, to znamená väzňov odsúdených na smrt', v úzkom prepojení na predchádzajúce verše, zachytáva Pilinszký i v básni s názvom Francouzský vězeň. V jej záverečnej strofe sa opätovne autorovi vynára ničím nezabudnutel'ný obraz hladu, utrpenia, smrti, doslova hlas väzňov, ktorí, hoci mnohí pomreli, žijú nad’alej v jeho mysli, srdci, priam v duši ${ }^{30}$ :

25 J. Pilinszky, Ortel, Praha 1999, s. 151.

${ }^{26}$ Na spomenuté aspekty básní, ktoré sa viažu ku konkrétnemu dátumu a miestu, podnecujúce autora k ich napísaniu, upriamil pozornost' Zoltán Szénási (Mad’arská akadémia vied v Budapešti) v štúdii s názvom Literatúra, teológia a modernita (Historická, existenciálna a náboženská skúsenost' v básnickom diele Jánosa Pilinszkého), publikovanej v periodiku „World Literature Studies“, 2014, č. 1 , s. 80.

27 J. Pilinszky, Ortel, s. 48.

28 Ibidem.

${ }^{29}$ Ibidem, s. 49.

${ }^{30}$ Hoci v inom kontexte udalostí druhej svetovej vojny, ale v hlavnom zmysle analogickom, možno v súvislosti s týmto Pilinszkého motívom ,večnej spomienky“ na utrpenie a smrt' väzňov z koncentračných táborov spomenút' novelu slovenského spisovatel'a židovského pôvodu Leopolda Laholu s názvom Rozhovor s nepriatel'om (napísaná v roku 1954, je súčast'ou prozaickej zbierky Posledná vec, publikovanej v roku 1968), ktorá sa stala i námetom na filmovú adaptáciu. Jej hlavnými predstavitel'mi 
„Mám hlad!““ — Tu cítím přestrašlivý hlad, / ten bez úkoje, který zůstává, / byt’ nebožák ho dávno necítí, / jejž neutiší žádná potrava. / Ted’ žije ze mne. Stále hladověji. / Já mu čím dál míň stačím vyjít vstříc. / Ten, jemuž k jídlu stačilo kdys vše, / ted' žádá už mé srdce — a víc nic ${ }^{31}$.

Napokon básne ako Ravensbrücká pašije, Třetího dne či Frankfurt smerujú i k zobrazeniu istej paralely medzi utrpením Ježiša Krista a väzňov v koncentračných táboroch, pretože v kontexte zachytených udalostí v komparácii s biblickou textovou tradíciou a v dialógu s n̆ou sa holokaust stáva ak aj nie pochopitel'ný, tak aspoň vyrozprávatel'ný ${ }^{32}$. Posledné dve menované básne dokonca zvýrazňujú motív Kristovho vzkriesenia, ktorým premohol smrt', v súvislosti s utrpením väzňov, pričom práve v kontexte jeho neskoršie vydaných denníkových záznamom možno pochopit' tento hlbší zmysel:

Vody vracajú sa spät’ do mora: «zomrú» v ňom. V skutočnosti nezaniknú, len sa vrátia domov. Tento paradox je hádam najkrajším a najobjasňujúcejším obrazom, metaforou smrti. Žit' sa dá aj tak, aj tak, spolu s tým alebo oným, ale zomriet' sa dá len s najpodstatnejšími vecami. Smrt' v skutočnosti ani neexistuje, aspoň nie tá smrt’, ktorú môžeme zvonku ,zazriet““. Musíme najprv žit', aby sme mohli vziat' smrt' na vedomie. V skutočnosti nemáme schopnosti na to, aby sme spoznali fyzickú smrt'. Život človeka — tak to cítim ja — sa len zvonku zdá rovnou čiarou vedúcou od kolísky po hrob, kde sa roztrhne. Presnejšie: fyzická smrt’ nie je totožná so skutočnou smrtou. Cítim to tak, že zomierame zakaždým, ked' naozaj žijeme: vtedy, ked’ „zomrieme“ prežitím poznania, pravdy, radosti či zármutku. Vtedy, ked' zabudneme na seba a predsa potom v nekonečnom rozmnožení dostaneme spät' samých seba. Stručne povedané: ked' sa navrátime do otcovského domu, do mora reality ${ }^{33}$.

Motív smrti — a s ním úzko súvisiace motívy ako samota, zánik, ničota, utrpenie, bolest', opustenost', pominutel'nost' — vnímaný cez rôzne pohl'ady, dôvody, okolnosti, významy, umelecky zachytené vo vybraných dielach stredoeurópskych katolíckych autorov 20. storočia (J. Deml, J. Zahradníček, P. Strauss, P. U. Oliva, J. Pilinszký), nachádzajú svoj spojovací moment práve vo viere v nesmrtel'nú l'udskú dušu, v jej povolaní života vo večnosti, a teda vo vnímaní

sú nemecký vojak Helmut Kampen a zajatý Partizán, ktorého má Nemec príkaz zastrelit'. Ten sa však rozhodol rozkaz neuposlúchnut' a vedie s ním filozofický rozhovor o tom, akým spôsobom môže žit' človek po smrti aj nad'alej. Uvažovanie nad položenou otázkou Helmuta Kampena o nesmrtel'nosti možno považovat' za leitmotív celej novely, ktorej konečné riešenie nachádzame až v jej úplnom závere. Po dejovom obrate, kedy sa väzňom partizánskej skupiny stane H. Kampen, má predtým zajatý Partizán, po príkaze komisára, zabit' Kampena. Hoci sa mu do toho nechce, pretože filozofia nemeckého vojaka v ňom vyvolala mnoho otázok, tesne predtým, ako má stlačit’ spúšt', Kampen rozrieši otázku, na ktorú si nevedel dat' dlho odpoved’ a prezrádza ju aj svojmu vrahovi — Partizánovi: „,- Mám to, povedal. - Človek žije d'alej hoci aj vo svojom nepriatel'ovi, ktorý ho zabil“". Hoci Pilinszký nebol vrahom, jeho desivé spomienky na hrôzy druhej svetovej vojny a holokaust v ňom — a tým pádom aj $\mathrm{v}$ jeho tvorbe - zanechali pravdepodobne nadlho podobný pocit, aký vyslovil tesne pred smrtou nemecký vojak v Laholovej novele.

31 J. Pilinszky, Ortel..., s. 51-52.

32 Z. Szénási, Literatúra, teológia..., s. 80.

33 J. Pilinszky, Namiesto ars poetiky (z denníkov), prel. M. Haugová, „Romboid“ 2013, č. 8 (48), s. 42 . 
smrti ako prechodu do hierarchizovaného posmrtného bytia, zaručené Kristovou smrtou na kríži, ktorý samotnú entitu smrti premohol svojím vzkriesením. Citujúc Jánosa Pilinszkého:

Život človeka, naše životy vyzerajú zvonka ako vodorovná čiara vedúca od narodenia po hrob. Ale skutočná realita nášho života sa odohráva v hĺbkach a výškach vertikály, presnejšie povedané: naraz na obidvoch rovinách, čiže v ,realite kríža“34.

\section{Bibliografie}

Balajka B., Blajer Z., Charous E., Přehledné dějiny literatury II, Praha 1994.

Deml J., Sen jeden svití, Praha 1991.

Deml J., Moji prátelé, http://www.deml.cz/moji-pratele.

Gallik J., Katolícka moderna v stredoeurópskom kontexte, [in:] Literárna komparatistika v súvislostiach, ed. D. Teplan, Nitra 2016.

Gallik J., Slovenská katolicka literatúra v stredoeurópskom priestore, Nitra 2015.

Hajdučeková I., Duchovnost’v (re)interpretácii diel slovenskej literatúry, Košice 2016.

Hajko D., Antické provokácie, Bratislava 2016.

Juhásová J., Od symbolu k latencii, Ružomberok 2016.

Koleják M., Pavol Strauss — hladač pravdy, Gelnica 2013.

Kučera P., Žánr katolické poezie v postmoderni situaci, „Slavica Litteraria” 2015, č. 2 (18).

Med. J., Literární život ve stínu Mnichova (1938-1939), Praha 2010.

Med. J., Spisovatelé ve stínu, Praha 2004.

Němá nauka stromů o spáse. Antologie mad'arské katolické literatury, eds. R. K. Szemán, S. Kolmanová, Praha 2014.

Oliva P., Tak umieral a žije Pal’o Oliva 2, Bratislava 2004.

Oliva P., Torzo literárneho diela 1, Bratislava 2004.

Pašteka J., Tvár a tvorba slovenskej katolíckej moderny, Bratislava 2002.

Pilinszky J., Namiesto ars poetiky (z denníkov), prel. M. Haugová, „Romboid” 2013, č. 8 (48).

Pilinszky J., Ortel, Praha 1999.

Rybák J., Posledný rok s Pavlom Straussom, Gelnica 2015.

Strauss P., Človek pre nikoho, Bratislava 2000.

Strauss P., Koliska dôvery, Trnava 1994.

Strauss P., O smrti, „Listy PS“ 2014, č. 5.

Szénási Z., Literatúra, teológia a modernita (Historická, existenciálna a náboženská skúsenost'v básnickom diele Jánosa Pilinszkého), ,World Literature Studies“ 2014, č. 1.

Zahradníček J., Knihy básní, Praha 2001.

${ }^{34}$ Ibidem.

Slavica Wratislaviensia 168, 2019

(C) for this edition by CNS 


\section{Motif of death in the work of Slovak, Czech and Hungarian authors of Catholic literature}

\section{Summary}

In the context of the evolution of religious literature, including the poetics of Slovak, Czech and Hungarian Catholic literature, the motif of death is not particularly unusual. This fact is clearly noticeable in the work of authors of the turn of the 19th century and the entire 20th century, as well as in the following millennium. For example, in the first phase of the creative work of Jakub Deml, who is considered one of the most important representatives of Czech Catholic literature of the first half of the 20th century, mirroring the so-called apocalyptic realism, we notice the thematization of solitude, death, extinction and nothingness. Death in Deml's work is depicted as an entity that one seeks with an affection and desire, while "it constantly encounters Life. But as soon as they get excited and look for Life, they constantly meet Death, even those who don't look for one for themselves". Few years afterwards, a very similar thesis was developed by the later Catholic convert, important thinker and — it can be said - a comrade of the author of Slovak Catholic modernism, Pavol Strauss: "Life consists of search for life and it finds death within". A Hungarian writer János Pilinszky, who besides (spiritual-Christian) poetry wrote great essays, the so-called Lyrical Diaries, wrote regarding death: "Death doesn't exist for real, at least not the one that can be seen from the outside. We have to live first to be able to consider death". And finally, Jan Zahradníček in his debut collection shifts the perception of death to the next semantic level, when it his poem Their shadow he writes "for the living ones I was alive too much / and for the alive ones I was too dead". The aim of this paper is to interpret the motif of death in the work of selected authors of the Slovak, Czech and Hungarian Catholic literature.

Keywords: motif, death, extinction, eternity, Catholic literature

\section{Motyw śmierci w twórczości słowackich, czeskich i węgierskich autorów literatury katolickiej}

\section{Streszczenie}

W kontekście rozwoju twórczości religijnej, w tym poezji słowackiej, czeskiej i węgierskiej literatury katolickiej, motyw śmierci nie jest niczym wyjątkowym. Zjawisko to można zaobserwować również w dziełach autorów z przełomu XIX i XX wieku. Motyw śmierci pojawia się w całej dwudziestowiecznej literaturze i przechodzi do trzeciego tysiąclecia. Występuje na przykład u Jakuba Demla, który jest uważany za jednego z najwybitniejszych przedstawicieli czeskiej literatury katolickiej pierwszej połowy XX wieku. W pierwszym okresie jego twórczości, w czasie tak zwanego realizmu apokaliptycznego, można zauważyć, że tematyka utworów krąży wokół samotności, śmierci, zaniku i nicości.

Pavol Staruss, wybitny myśliciel katolicki, konwertyta z judaizmu i - można powiedzieć — wierny towarzysz autorów słowackiego modernizmu katolickiego, często podkreślał, iż życie składa się z poszukiwania życia, a w ramach tych poszukiwań natrafia się na śmierć. Z kolei János Pilinszky - węgierski pisarz, który oprócz duchowo-chrześcijańskiej twórczości poetyckiej tworzył wspaniałe eseje i tak zwane dzienniki liryczne — pisał w odniesieniu do śmierci, że śmierć 
w rzeczywistości nie istnieje, przynajmniej nie ta śmierć, którą możemy zaznać z zewnątrz. Trzeba najpierw żyć, abyśmy mogli wziąć pod uwagę śmierć.

I wreszcie Jan Zahradníček w swoim debiutanckim tomiku przesuwa pojęcie śmierci na inny poziom znaczeniowy. W wierszu Ich cień umieszcza strofę: ,dla martwych byłem za bardzo żywy / a dla żywych za bardzo martwy".

Celem tego artykułu jest przedstawienie przeglądu i dokonanie interpretacji twórczości wybranych autorów słowackiej, czeskiej i węgierskiej literatury katolickiej pod kątem występującego w niej motywu śmierci.

Słowa kluczowe: motyw, śmierć, wieczność, literatura katolicka, zagłada 